ISSN 1392-3196 / e-ISSN 2335-8947

Zemdirbyste-Agriculture, vol. 100, No. 2 (2013), p. 127-136

DOI 10.13080/z-a.2013.100.016

\title{
Response of common barley (Hordeum vulgare L.) physiological parameters to agricultural practices and meteorological conditions
}

\author{
Daiva JANUŠAUSKAITĖ, Ona AUŠKALNIENĖ, Dalia FEIZIENĖ, Virginijus FEIZA \\ Institute of Agriculture, Lithuanian Research Centre of Agriculture and Forestry \\ Instituto 1, Akademija, Kèdainiai distr., Lithuania \\ E-mail: daiva.janusauskaite@1zi.lt
}

\begin{abstract}
Little is known about the response of spring barley (Hordeum vulgare L.) physiological parameters to stand density, on which barley productivity depends. The aim was to establish the contrasts of physiological parameters between the different varieties and different stand densities under field conditions and the interaction between physiological parameters and meteorological factors of Lithuania (East Europe). The test involved three barley varieties and three stand densities. The measurements were made three times during the growing season. Varietal and stand density effect on photosynthetic rate, transpiration rate, and instantaneous water use efficiency was more strongly expressed in wet conditions compared with dry conditions. The spring barley varieties differed in the tolerance of meteorological factors throughout the growing season. The photosynthetic process was more intensive for the

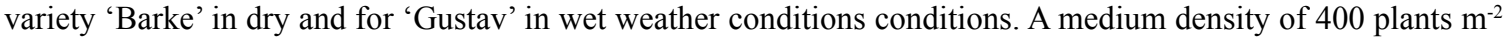
was the optimum. With the change in stand density, physiological parameters tended to decrease in most of the tested cases. The interaction of meteorological factors influenced the mean of photosynthetic rate across stand densities by $52.1,67.1$ and $73.6 \%$ and the mean of transpiration rate by $63.3,61.1$ and $72.0 \%$ for 'Aura DS', 'Barke' and 'Gustav', respectively.
\end{abstract}

Key words: gas exchange, Hordeum vulgare, stand density, varieties.

\section{Introduction}

Barley (Hordeum) is one of the most popular cereals belonging to the grass (Poaceae) family. It is now being cultivated in different parts of the world where different environmental factors are affecting plant growth, photosynthesis process and yield (Tambussi et al., 2005; Jiang et al., 2006; Kalaji et al., 2011). It is important for barley growers to better understand the factors affecting the photosynthetic productivity. Studies performed on different crops have indicated that the climate warming and changes in moisture and thermal regimes intensely influence the photosynthesis process (Gonzalez et al., 2010; Waraich et al., 2011 a; Zhao et al., 2011). Knowledge of the physiological traits that limit yield under inimical conditions provides new opportunities for future breeding and growing strategies (Tambussi et al., 2005; Gonzalez et al., 2010; Kalaji et al., 2011). Photosynthetic traits significantly differ between the different genotypes (Anyia, Herzog, 2004; Mamnouie et al., 2006), and between both open field and greenhouse growing conditions (Ibrahim, Jaafar, 2011). Intensity of photosynthesis varies throughout plant development stages (Tsialtas, Maslaris, 2008; Efthimiadou et al., 2010). The reduction of photosynthesis has direct effect on crop growth and yield (Gonzalez et al., 2010). This is important to consider while developing new technologies of barley cultivation. The factors related to the photosynthesis process, such as photosynthetic rate, transpiration, stomatal conductance and instantaneous water use efficiency can be used as selection criteria for the improvement of crop yield potential (Anyia, Herzog, 2004; Tambussi et al., 2005; Ibrahim, Jaafar, 2011). The relationship between photosynthetic parameters and chlorophyll index (SPAD) in the foliage is also important (Janušauskaitè et al., 2012).

There are no data about the influence of crop stand density on physiological parameters. Plant growth depends on photosynthesis which is affected by environmental factors such as temperature, nutrition and light (Cai et al., 2008; Niu et al., 2008). Conditions inimical to growth may cause stress, which may be apparent in morphological and physiological characteristics and represent integrated responses to multiple environmental factors. It was established that the low stand density (SD) allowed more energy to reach the soil, from which it was reflected, making a considerable contribution to the final temperature in the stand and water transpiration from soil and foliage (Anda, Løke, 2005). The plants in a denser stand have inter-competition pressure not only for nutrition, but also for light, and a lower light intensity inside the stand leads to a lower carbon gain of the individual plants (Del Pozo, Dennett, 1999). As a result, an increase in the SD could be considered a stress condition.

The effect of SD on physiological characteristics of spring barley grown under field conditions has 
not been extensively studied. In addition, there is not enough information about the effect of the different seed rate on photosynthetic rate $(\mathrm{A})$, transpiration rate $(\mathrm{E})$, stomatal conductance (gs) and instantaneous water use efficiency (WUE $i$ ) of widely cultivated varieties in our region. The main objective of the present study was to establish the contrasts in A, E, gs and WUE $i$ between the different varieties and different stand densities throughout development stages exclusively under open field conditions. In addition, the interaction between physiological parameters and meteorological factors under field conditions of Lithuania (East Europe) was also assessed in this study.

\section{Materials and methods}

Study site. Field experiments were carried out at the Lithuanian Institute of Agriculture (currently Lithuanian Research Centre for Agriculture and Forestry) in Central Lithuania $\left(55^{\circ} 23^{\prime} 50^{\prime \prime} \mathrm{N}\right.$ and $\left.23^{\circ} 51^{\prime} 40^{\prime \prime} \mathrm{E}\right)$ during 2008-2009. The soil type of the experimental field is an Endocalcari-Endohypogleyic Cambisol (CMg$n-w$-can). According to fractions of soil aggregates: $52-$ $54 \%$ sand $(2.0-0.05 \mathrm{~mm}), 29-32 \%$ silt $(0.05-0.002 \mathrm{~mm})$ and $14-19 \%$ clay $(<0.002 \mathrm{~mm})$, soil was medium loam. The concentration of available $\mathrm{P}_{2} \mathrm{O}_{5}$ (A-L method) varied from 74 to $122 \mathrm{mg} \mathrm{kg}^{-1}$, available $\mathrm{K}_{2} \mathrm{O}$ (A-L method) from 133 to $199 \mathrm{mg} \mathrm{kg}^{-1}, \mathrm{pH}_{\mathrm{KCl}}$ from 6.0 to 6.1 , humus from $1.7 \%$ to $2.3 \%$ in $0-25 \mathrm{~cm}$ soil layer.

Plant material and agricultural practices. The recommended stand density of spring barley in Central Lithuania is 4 million plants per hectare. Treatments included three stand densities (SDs) with the seed rates of 200 (SD I), 400 (SD II) and 600 (SD III) plants $\mathrm{m}^{-2}$ and three spring barley (Hordeum vulgare L.) varieties 'Aura DS', 'Barke' and 'Gustav'. The plants of variety 'Aura DS' are broad-leaved, tall, mid maturity. Variety 'Barke' is of middle shading ability, medium tall, quite broad-leaved. The plants of variety 'Gustav' are of the lowest shading ability with short stems. The experimental design was a split plot with four replications. Barley varieties were laid out in the main plot and the stand density in the subplot. Spring wheat (Triticum aestivum L.) was a pre-crop. Spring barley was fertilized with $\mathrm{N}_{60} \mathrm{P}_{60} \mathrm{~K}_{60}$ before sowing. The soil was ploughed in the autumn. Spring barley was sown with a small plot drill "Wintersteiger Tool Carrier
2700 " (Germany) in spring. The row spacing was $12 \mathrm{~cm}$, sowing depth $2-3 \mathrm{~cm}$. The herbicides were applied: in 2008 - MCPA (MCPA) (0.75 $\left.1 \mathrm{ha}^{-1}\right)$ and Lintur $70 \mathrm{WG}$ (triasulfuron + dicamba) $\left(120 \mathrm{~g} \mathrm{ha}^{-1}\right)$ and in 2009 - Lintur $70 \mathrm{WG}\left(120 \mathrm{~g} \mathrm{ha}^{-1}\right)$. The stand crop was sprayed with fungicides: in 2008 -Archer Top $400 \mathrm{EC}$ (propiconazole + fenpropidin) $\left(1.01 \mathrm{ha}^{-1}\right), 2009$ Falcon $460 \mathrm{EC}$ (tebuconazole + triadimenol + spiroxamin $)\left(0.61 \mathrm{ha}^{-1}\right)$.

Leaf gas exchange measurements. Leaf gas exchange measurements including photosynthetic rate (A), transpiration rate (E), and stomatal conductance (gs) were determined using a portable gas analyser SRS-1000 (ADC BioScientific Ltd., UK). The SRS-1000 system consists of the compact programming console and leaf chamber, which has a square $\left(6.25 \mathrm{~cm}^{2}\right)$ aperture sealed. The attached flag leaf was placed into the chamber and $\mathrm{A}$ was recorded in data logger in about two minutes, when no noticeable changes in leaf respiration were registered. The measurements were made from 2 p.m. till 4 p.m. four times on clear days throughout growing season - at first node growth stage (GS) (corresponding to code $\mathrm{BBCH}$ 31 ), at booting GS (BBCH 45), end of heading GS (BBCH $59)$ and at watery ripe (BBCH 71) in two replications of each trial treatment. The dates of the investigated GS in 2008 were 29 May, 9 June, 26 June and 11 July, in 2009 10 June, 17 June, 29 June and 8 July. The measurements were made on a randomly selected first fully expanded leaf from the top of each plot. The values of $A$ and $E$ were used to calculate the instantaneous water use efficiency (WUE $i=\mathrm{A} / \mathrm{E})$.

Meteorological data. Weather conditions were one of the tested parameters. The weather conditions varied throughout the experimental years (Table 1). The period of May-July in 2008, compared to the long term mean, was dry - as little as $21 \%$ of long-term mean of rainfall fell in May, $67 \%$ in June, and 64\% in July, respectively. However, the air temperature was more or less similar to the long-term mean: in May it was equal, in June $0.5^{\circ} \mathrm{C}$ and in July $0.6^{\circ} \mathrm{C}$ above the long-term mean. In 2009 like in 2008, there was a shortage of rainfall in May when $52 \%$ of the long-term mean fell, nonetheless in June and July the total rainfall amounted to $270 \%$ and $123 \%$ of the long-term mean, respectively. The mean air temperature was similar to that in $2008-0.5^{\circ} \mathrm{C}$ above the long-term mean in May and July and in June it was $1.0^{\circ} \mathrm{C}$ below the long-term mean.

Table 1. Meteorological conditions during the spring barley growing season (Dotnuva Weather Station)

\begin{tabular}{|c|c|c|c|c|c|c|c|c|}
\hline \multirow[b]{3}{*}{ Month } & \multicolumn{4}{|c|}{2008} & \multicolumn{4}{|c|}{2009} \\
\hline & \multicolumn{2}{|c|}{ Air temperature ${ }^{\circ} \mathrm{C}$} & \multicolumn{2}{|c|}{ Precipitation $\mathrm{mm}$} & \multicolumn{2}{|c|}{ Air temperature ${ }^{\circ} \mathrm{C}$} & \multicolumn{2}{|c|}{ Precipitation $\mathrm{mm}$} \\
\hline & $\begin{array}{c}\text { Monthly } \\
\text { mean }\end{array}$ & $\begin{array}{l}\text { Difference } \\
\text { from long- } \\
\text { term mean }\end{array}$ & $\begin{array}{c}\text { Monthly } \\
\text { mean }\end{array}$ & $\begin{array}{l}\text { Difference } \\
\text { from long- } \\
\text { term mean }\end{array}$ & $\begin{array}{c}\text { Monthly } \\
\text { mean }\end{array}$ & $\begin{array}{l}\text { Difference } \\
\text { from long- } \\
\text { term mean }\end{array}$ & $\begin{array}{c}\text { Monthly } \\
\text { mean }\end{array}$ & $\begin{array}{l}\text { Difference } \\
\text { from long- } \\
\text { term mean }\end{array}$ \\
\hline April & 8.8 & +3.0 & 38.7 & +1.5 & 8.8 & +3.0 & 13.1 & -23.8 \\
\hline May & 12.2 & 0 & 13.2 & -38.9 & 12.7 & +0.5 & 26.7 & -25.1 \\
\hline June & 16.1 & +0.5 & 49.2 & -11.9 & 14.6 & -1.0 & 168.6 & +106.2 \\
\hline July & 18.2 & +0.6 & 47.6 & -25.7 & 18.1 & +0.5 & 90.0 & +16.6 \\
\hline August & 18.0 & +1.3 & 90.8 & +17.0 & 16.8 & +0.1 & 67.1 & -6.6 \\
\hline
\end{tabular}

Statistical analysis. Analysis of variance $(P<0.05)$ based on a three-factorial (factor A - variety, factor B - SD, factor C - GS) split-plot design model were performed using the ANOVA, STATISTICA package. Significance of treatment effects was analyzed by the Fisher LSD (least significant difference). Also, the experimental data were processed by correlation regression analysis method using STAT-ENG. 


\section{Results and discussion}

The meteorological conditions were diverse in the experimental years (Table 1), therefore the results were separately analysed and discussed for 2008 and 2009. The varietal influence on photosynthetic rate (A) and instantaneous water use efficiency (WUE $i$ ) was significant $(P \leq 0.05)$ in 2008 (Table 2$)$. Stand density (SD) significantly $(P \leq 0.05, P \leq 0.01)$ influenced transpiration rate (E) and WUE $i$. The growth stage (GS) significantly influenced $(P \leq 0.05)$ all parameters $-\mathrm{A}, \mathrm{E}$, WUE $i$ and stomatal conductance (gs) in 2008.

The influence of variety and SD on A and WUE $i$ was significant at $P \leq 0.01$ and on $\mathrm{E}$ was significant at $P \leq 0.05$ in 2009 . All parameters were influenced by GS at $P \leq 0.01$. The variety and stand density effect on gs was insignificant in both years.

Table 2. Analysis of variance of photosynthetic parameters

\begin{tabular}{|c|c|c|c|c|c|c|c|}
\hline \multirow[b]{2}{*}{ Indicator } & \multicolumn{7}{|c|}{ Factor } \\
\hline & $\begin{array}{c}\text { Variety } \\
\text { (factor A) }\end{array}$ & $\begin{array}{c}\mathrm{SD} \\
\text { (factor B) }\end{array}$ & $\begin{array}{c}\mathrm{GS} \\
\text { (factor } \mathrm{C} \text { ) }\end{array}$ & $\mathrm{A} \times \mathrm{B}$ & $\mathrm{A} \times \mathrm{C}$ & $\mathrm{B} \times \mathrm{C}$ & $\mathrm{A} \times \mathrm{B} \times \mathrm{C}$ \\
\hline \multicolumn{8}{|c|}{2008} \\
\hline $\mathrm{A}$ & $*$ & ns & $* *$ & ns & $*$ & ns & ns \\
\hline E & ns & $*$ & $* *$ & ns & $*$ & $\mathrm{~ns}$ & ns \\
\hline WUE $i$ & $*$ & $* *$ & $* *$ & ns & ns & ns & ns \\
\hline gs & ns & ns & $* *$ & ns & ns & ns & ns \\
\hline \multicolumn{8}{|c|}{2009} \\
\hline $\mathrm{A}$ & $* *$ & $* *$ & $* *$ & $* *$ & $* *$ & ns & $* *$ \\
\hline E & $*$ & $*$ & $* *$ & ns & $* *$ & $\mathrm{~ns}$ & $*$ \\
\hline WUE $i$ & $* *$ & $* *$ & $* *$ & ns & $* *$ & ns & $* *$ \\
\hline gs & ns & ns & $* *$ & $*$ & $* *$ & ns & $* *$ \\
\hline
\end{tabular}

$\mathrm{SD}$ - stand density, GS - growth stage, A - photosynthetic rate, E - transpiration rate, WUE $i$ - instantaneous water use efficiency, gs - stomatal conductance; $*-P \leq 0.05, * *-P \leq 0.01$, n.s. - non-significant

Variation of photosynthetic rate $(A)$ and transpiration rate $(E)$ of spring barley. The variety 'Barke' was characterized by higher A in 2008. Averaged across SD, mean of A was highest for the variety 'Barke' in three cases out of four - at BBCH 31, BBCH 45 and at $\mathrm{BBCH} 71$ and was 8.10, 13.12 and $2.71 \mu \mathrm{mol} \mathrm{CO} \mathrm{m}^{-2} \mathrm{~s}^{-1}$, respectively (Table 3 ). The differences between A values of the variety 'Barke' and mean of trial were significant at intensive growth period of barley and they were found to be $0.87 \mu \mathrm{mol} \mathrm{CO} \mathrm{m}^{-2} \mathrm{~s}^{-1}$ at $\mathrm{BBCH} 31$ and $2.13 \mu \mathrm{mol}$ $\mathrm{CO}_{2} \mathrm{~m}^{-2} \mathrm{~s}^{-1}$ at $\mathrm{BBCH} 45$.

Table 3. Effects of variety and stand density (SD) on photosynthetic rate $\left(\mathrm{A}, \mu \mathrm{mol} \mathrm{CO}_{2} \mathrm{~m}^{-2} \mathrm{~s}^{-1}\right)$ and transpiration rate $\left(\mathrm{E}, \mathrm{mmol} \mathrm{H}_{2} \mathrm{O} \mathrm{m}^{-2} \mathrm{~s}^{-1}\right)$, in 2008

\begin{tabular}{|c|c|c|c|c|c|c|c|c|c|}
\hline \multirow{2}{*}{ Variety } & \multirow{2}{*}{ SD } & \multicolumn{2}{|c|}{ BBCH 31} & \multicolumn{2}{|c|}{ BBCH 45} & \multicolumn{2}{|c|}{ ВBCH 59} & \multicolumn{2}{|c|}{ BBCH 71} \\
\hline & & A & $E$ & A & $\mathrm{E}$ & A & $\mathrm{E}$ & A & $E$ \\
\hline \multirow{3}{*}{ 'Aura DS' } & SD I & 7.52 & 1.61 & 10.14 & 2.91 & 7.96 & 2.88 & 3.33 & 1.80 \\
\hline & SD II & 6.33 & 1.15 & 9.92 & 2.56 & 9.57 & 3.17 & 2.06 & 1.54 \\
\hline & SD III & 6.97 & 1.58 & 9.07 & 2.60 & 7.47 & 2.82 & 2.40 & 1.37 \\
\hline \multirow{3}{*}{ 'Barke' } & SD I & 8.61 & 1.86 & 12.20 & 2.76 & 7.01 & 3.06 & 3.38 & 1.72 \\
\hline & SD II & 7.42 & 1.62 & 12.76 & 3.08 & 8.88 & 2.24 & 2.39 & 1.33 \\
\hline & SD III & 8.28 & 1.88 & 14.39 & 2.85 & 4.27 & 2.32 & 2.36 & 1.86 \\
\hline \multirow{3}{*}{ 'Gustav' } & SD I & 7.45 & 1.64 & 9.28 & 2.55 & 8.87 & 3.64 & 2.22 & 1.39 \\
\hline & SD II & 5.13 & 1.67 & 9.63 & 3.33 & 6.88 & 3.13 & 0.46 & 1.08 \\
\hline & SD III & 7.36 & 1.47 & 11.56 & 2.82 & 8.47 & 3.06 & 1.31 & 1.01 \\
\hline \multicolumn{10}{|c|}{ Mean across SDs ${ }^{\mathrm{a}}$} \\
\hline 'Aura DS' & & $6.94 \mathrm{~b}$ & $1.44 \mathrm{c}$ & $9.71 \mathrm{c}$ & $2.69 \mathrm{~b}$ & $8.33 \mathrm{~b}$ & $2.96 \mathrm{~b}$ & $2.59 \mathrm{~b}$ & $1.57 \mathrm{~b}$ \\
\hline 'Barke’ & & $8.10 \mathrm{a}$ & $1.79 \mathrm{a}$ & $13.12 \mathrm{a}$ & $2.90 \mathrm{~b}$ & $6.72 \mathrm{~b}$ & $2.54 \mathrm{c}$ & $2.71 \mathrm{~b}$ & $1.63 \mathrm{~b}$ \\
\hline 'Gustav' & & $6.64 \mathrm{c}$ & $1.59 \mathrm{~b}$ & $10.16 \mathrm{~b}$ & $2.90 \mathrm{~b}$ & $8.07 \mathrm{~b}$ & $3.28 \mathrm{a}$ & $1.33 \mathrm{c}$ & $1.16 \mathrm{c}$ \\
\hline \multicolumn{10}{|c|}{ Mean across varieties ${ }^{\mathrm{a}}$} \\
\hline & SD I & $7.86 \mathrm{~b}$ & $1.70 \mathrm{~b}$ & $10.54 \mathrm{~b}$ & $2.74 \mathrm{~b}$ & $7.95 \mathrm{~b}$ & $3.19 \mathrm{a}$ & $2.97 \mathrm{a}$ & $1.63 \mathrm{~b}$ \\
\hline & SD II & $6.29 \mathrm{c}$ & $1.48 \mathrm{c}$ & $10.77 \mathrm{~b}$ & $2.99 \mathrm{~b}$ & $8.44 \mathrm{~b}$ & $2.85 \mathrm{~b}$ & $1.63 \mathrm{~b}$ & $1.32 \mathrm{~b}$ \\
\hline & SD III & $7.53 \mathrm{~b}$ & $1.64 \mathrm{~b}$ & $11.67 \mathrm{~b}$ & $2.76 \mathrm{~b}$ & $6.74 \mathrm{~b}$ & $2.74 \mathrm{~b}$ & $2.02 \mathrm{~b}$ & $1.41 \mathrm{~b}$ \\
\hline Mear & rial & 7.23 & 1.61 & 10.99 & 2.83 & 7.71 & 2.92 & 2.21 & 1.45 \\
\hline \multicolumn{10}{|c|}{ Significance } \\
\hline \multirow{3}{*}{\multicolumn{2}{|c|}{$\begin{array}{c}\text { Variety }(\text { factor A) } \\
\mathrm{SD}(\text { factor B) } \\
\mathrm{A} \times \mathrm{B}\end{array}$}} & $*$ & $* *$ & $* *$ & ns & ns & ** & $*$ & ns \\
\hline & & ns & ns & ns & ns & ns & ns & ns & ns \\
\hline & & ns & ns & ns & ns & ns & ns & ns & ns \\
\hline
\end{tabular}

Note. BBCH 31 - stem elongation, first node, BBCH 45 - booting, BBCH 59 - end of heading, BBCH $71-$ watery ripe; * $-P \leq$ $0.05,{ }^{*} * P \leq 0.01,{ }^{\text {a }}-$ numbers followed by different letter within a set of the column are significantly different at $P \leq 0.05$ by the least square means test.

A mean of trial varied throughout GS in 2009 (Table 4). The maximum of A was established at $\mathrm{BBCH}$ 31 . A mean of trial decreased by $30 \%$ at $\mathrm{BBCH} 45$, and by
$33.1 \%$ at $\mathrm{BBCH} 59$ and by $35.0 \%$ at $\mathrm{BBCH} 71$ compared with previous assessment at $\mathrm{BBCH} 31, \mathrm{BBCH} 45$ and $\mathrm{BBCH} 59$, respectively. 
Table 4. Effects of variety and stand density (SD) on photosynthetic rate $\left(\mathrm{A}, \mu \mathrm{mol} \mathrm{CO}_{2} \mathrm{~m}^{-2} \mathrm{~s}^{-1}\right)$ and transpiration rate $\left(\mathrm{E}, \mathrm{mmol} \mathrm{H}_{2} \mathrm{O} \mathrm{m}^{-2} \mathrm{~s}^{-1}\right)$, in 2009

\begin{tabular}{|c|c|c|c|c|c|c|c|c|c|}
\hline \multirow{2}{*}{ Variety } & \multirow{2}{*}{$\mathrm{SD}$} & \multicolumn{2}{|c|}{ BBCH 31} & \multicolumn{2}{|c|}{ BBCH 45} & \multicolumn{2}{|c|}{ BBCH 59} & \multicolumn{2}{|c|}{ BBCH 71} \\
\hline & & $\mathrm{A}$ & $\mathrm{E}$ & $\mathrm{A}$ & $\mathrm{E}$ & $\mathrm{A}$ & $\mathrm{E}$ & $\mathrm{A}$ & $E$ \\
\hline \multirow{3}{*}{ 'Aura DS' } & SD I & 6.23 & 3.64 & 5.27 & 3.08 & 2.03 & 2.39 & 0.75 & 2.92 \\
\hline & SD II & 8.42 & 3.32 & 7.62 & 3.11 & 3.14 & 2.42 & 2.28 & 3.61 \\
\hline & SD III & 7.53 & 3.43 & 3.46 & 2.55 & 5.55 & 2.85 & 3.71 & 2.80 \\
\hline \multirow{3}{*}{ 'Barke' } & SD I & 11.38 & 3.92 & 6.12 & 3.00 & 4.93 & 4.50 & 3.87 & 2.86 \\
\hline & SD II & 11.98 & 3.55 & 8.52 & 3.31 & 6.23 & 3.18 & 3.47 & 2.54 \\
\hline & SD III & 9.98 & 3.67 & 8.38 & 3.32 & 2.93 & 3.83 & 2.33 & 2.47 \\
\hline \multirow{3}{*}{ 'Gustav' } & SD I & 9.95 & 4.07 & 7.97 & 3.16 & 7.26 & 4.04 & 5.07 & 2.71 \\
\hline & SD II & 14.87 & 3.96 & 7.56 & 3.06 & 5.75 & 3.26 & 3.17 & 0.98 \\
\hline & SD III & 14.48 & 4.23 & 10.87 & 3.58 & 6.21 & 3.51 & 4.02 & 1.62 \\
\hline \multicolumn{10}{|c|}{ Mean across SDs ${ }^{\mathrm{a}}$} \\
\hline 'Aura DS' & & $7.39 \mathrm{c}$ & $3.46 \mathrm{c}$ & $5.45 \mathrm{c}$ & $2.91 \mathrm{~b}$ & $3.57 \mathrm{c}$ & $2.55 \mathrm{c}$ & $2.25 \mathrm{c}$ & $3.11 \mathrm{a}$ \\
\hline 'Barke' & & $11.11 \mathrm{~b}$ & $3.71 \mathrm{~b}$ & $7.67 \mathrm{~b}$ & $3.21 \mathrm{~b}$ & $4.70 \mathrm{~b}$ & $3.83 \mathrm{a}$ & $3.22 \mathrm{~b}$ & $2.62 \mathrm{~b}$ \\
\hline 'Gustav' & & $13.10 \mathrm{a}$ & $4.09 \mathrm{a}$ & $8.80 \mathrm{a}$ & $3.27 \mathrm{~b}$ & $6.41 \mathrm{a}$ & $3.60 \mathrm{~b}$ & $4.08 \mathrm{a}$ & $1.77 \mathrm{c}$ \\
\hline \multicolumn{10}{|c|}{ Mean across varieties ${ }^{\mathrm{a}}$} \\
\hline & SD I & $9.18 \mathrm{c}$ & $3.87 \mathrm{~b}$ & $6.45 \mathrm{c}$ & $3.08 \mathrm{~b}$ & $4.74 b$ & $3.64 \mathrm{~b}$ & $3.23 \mathrm{a}$ & $2.83 \mathrm{a}$ \\
\hline & SD II & $11.76 \mathrm{a}$ & $3.61 \mathrm{~b}$ & $7.90 \mathrm{~b}$ & $3.16 \mathrm{~b}$ & $5.04 \mathrm{~b}$ & $2.95 \mathrm{c}$ & $2.97 \mathrm{a}$ & $2.38 \mathrm{~b}$ \\
\hline & SD III & $10.66 \mathrm{~b}$ & $3.78 \mathrm{~b}$ & $7.57 \mathrm{~b}$ & $3.15 \mathrm{~b}$ & $4.89 \mathrm{~b}$ & $3.39 \mathrm{~b}$ & $3.35 \mathrm{a}$ & $2.30 \mathrm{~b}$ \\
\hline Mear & trial & 10.53 & 3.75 & 7.31 & 3.13 & 4.89 & 3.33 & 3.18 & 2.50 \\
\hline \multicolumn{10}{|c|}{ Significance } \\
\hline \multirow{3}{*}{\multicolumn{2}{|c|}{$\begin{array}{c}\text { Variety (factor A) } \\
\text { SD (factor B) } \\
\mathrm{A} \times \mathrm{B}\end{array}$}} & $* *$ & $* *$ & $* *$ & $\mathrm{~ns}$ & $* *$ & $* *$ & $*$ & $* *$ \\
\hline & & $* *$ & ns & ns & ns & ns & ns & ns & $*$ \\
\hline & & $*$ & ns & $* *$ & ns & $*$ & ns & $*$ & $* *$ \\
\hline
\end{tabular}

Explanations under Table 3

Under wet weather conditions in 2009, the response of the tested varieties differed in $\mathrm{A}$ and $\mathrm{E}$ compared with 2008. A was the highest for the variety 'Gustav' at all measurements (Table 4). Contrasts of A values 'Gustav' vs. trial mean were 24.4, 20.4, 31.1 and $28.3 \%$ higher at $\mathrm{BBCH} 31, \mathrm{BBCH} 45, \mathrm{BBCH} 59$ and $\mathrm{BBCH} 71$, respectively than the trial mean. Contrasts were significant and positive at all GS. The lowest A was established for the variety 'Aura DS' and contrasts 'Aura DS' vs. trial mean was significant and negative in all tested cases. All contrasts for 'Gustav' vs. trial mean were not significant. The study confirmed the existence of varietal differences in A of other plants. The influence of variety on A was significant $(P \leq 0.01)$ for 10 genotypes of winter wheat (Hui et al., 2008) and for six varieties of durum wheat (Abbad et al., 2004). The A values differed significantly amongst the ten genotypes by 3.01-5.09 $\mu \mathrm{mol} \mathrm{CO} \mathrm{m}^{-2} \mathrm{~s}^{-1}$ in cowpea (Anyia, Herzog, 2004). The differences in A among the seven rice varieties at each GS ranged between about 6 and 11 $\mu \mathrm{mol} \mathrm{CO} \mathrm{m}^{-2} \mathrm{~s}^{-1}$ (Takai et al., 2010). The A values of the flag leaf of winter wheat (Triticum aestivum L.) increased with cultivar development (Tian et al., 2011). Leaf A is closely related with many environmental factors, influencing plant physiology. The negative influence on $\mathrm{A}$ is exerted by inadequate nutrition (Fois et al., 2009) and the temperature of the leaf tissue (Niu et al., 2008; Ko, Piccinni, 2009; Takai et al., 2010). A limited water supply inhibits A of plants, causes changes of chlorophyll contents and components and damage to photosynthetic apparatus (Abbad et al., 2004; Waraich et al., 2011 a). Canopy architecture plays a significant role in light capture ability and A of canopy (Brooks et al., 2000). The arrangement, when the plants have vertical leaves at the top, becoming more horizontal near the bottom, spreads the light evenly between canopy, resulting in an increase in photosynthetic $\mathrm{CO}_{2}$ uptake, compared to the plant varieties with mostly horizontal leaves (Long et al., 2006). It is likely that in our experiment the different leaf architecture of the tested barley cultivars may have influenced A differences between cultivars.

Averaged across varieties, comparable contrasts of A between different SDs were significant $(P \leq 0.05)$ in $25 \%$ of the tested cases, i.e. for SD II $v s$. SD I at BBCH 31 and at BBCH 71 in 2008 (Table 3). Averaged across varieties in 2009, A comparable contrasts between different SDs were positive and the highest A was in SD II, but significant only in two cases, i.e. for SD II $v s$. SD I at BBCH $31-2.57 \mu \mathrm{mol} \mathrm{CO} \mathrm{m}^{-2} \mathrm{~s}^{-1}(P \leq 0.01)$ and at BBCH $45-1.44 \mu \mathrm{mol} \mathrm{CO} \mathrm{m}^{-2} \mathrm{~s}^{-1}(P \leq 0.05)$ (Table 4). Fang et al. (2010) found that increased seeding density reduced $(P<0.05)$ the $\mathrm{A}$ of flag leaf at winter wheat anthesis. There are data suggesting that $\mathrm{A}$ is affected by row spacing, not only by stand density; however, a more intensive rise of photosynthetic productivity was registered for increased sunflower hybrid density (Aksyonov, 2007).

A mean of trial differed throughout GS in 2008 (Table 3). A reached the maximum at $\mathrm{BBCH} 45$ and was higher by $52 \%$ compared with the first assessment at $\mathrm{BBCH} 31$. A mean of trial decreased by $30 \%$ at $\mathrm{BBCH}$ 59 and by $71 \%$ at $\mathrm{BBCH} 71$ compared with previous assessment at $\mathrm{BBCH} 45$ and $\mathrm{BBCH} 59$, respectively. The decline of A mean of trial in 2009 was more moderate than in 2008. The A mean of trial decreased by $30.5 \%$ at $\mathrm{BBCH}$ $45,33.1 \%$ at $\mathrm{BBCH} 59$ and $35.0 \%$ at $\mathrm{BBCH} 71$, compared with previous assessment at $\mathrm{BBCH} 31, \mathrm{BBCH} 45$ and BBCH 59, respectively (Table 4). The decline of A was found also for rice (Takai et al., 2010), maize (Efthimiadou et al., 2010), sugar beet (Tsialtas, Maslaris, 2008), cotton (Ko, Piccinni, 2009) during the growing season. Gutierrez et al. (2009) found that A declined between heading and 10-13 days after anthesis. Other authors indicated that the A of wheat flag leaves initially increased after anthesis, reaching a maximum on the $21^{\text {st }}$ day after anthesis, then gradually decreased (Cai et al., 2008).

Varietal responses of $\mathrm{E}$ were very similar to A in 2008. Averaged across SDs, the highest E values were 
determined for 'Barke' and they were by 11.1, 2.4 and $12.4 \%$ higher at $\mathrm{BBCH} 31, \mathrm{BBCH} 45$, and $\mathrm{BBCH} 71$, respectively than the trial mean (Table 3 ). Averaged across SDs in 2009, the highest $\mathrm{E}$ were determined for variety 'Gustav' at BBCH 31, BBCH 45 and the E values were higher by $0.33 \mathrm{mmol} \mathrm{H}_{2} \mathrm{O} \mathrm{m}^{-2} \mathrm{~s}^{-1}(9.1 \%)$ and $0.14 \mathrm{mmol}$ $\mathrm{H}_{2} \mathrm{O} \mathrm{m}^{-2} \mathrm{~s}^{-1}(4.5 \%)$, respectively than the trial mean (Table 4). The difference at BBCH 31 was significant $(P \leq$ $0.01)$. At the successive GS, the highest $\mathrm{E}$ was of 'Barke' and 'Aura DS' and was higher by $0.51 \mathrm{mmol} \mathrm{H}_{2} \mathrm{O} \mathrm{m}^{-2} \mathrm{~s}^{-1}$ $(15.0 \%, P \leq 0.01)$ and $0.61 \mathrm{mmol} \mathrm{H}_{2} \mathrm{O} \mathrm{m} \mathrm{m}^{-2} \mathrm{~s}^{-1}(24.4 \%$, $P \leq 0.01)$ compared with trial mean, respectively. In 2009 June third ten-day period, before a third measurement at $\mathrm{BBCH} 59$, plenty of rainfall fell $-78.3 \mathrm{~mm}$, the mean air temperature was $17.9^{\circ} \mathrm{C}$, i.e. $2.3^{\circ} \mathrm{C}$ above the longterm mean. With changing humidity and temperature, the response of barley varieties to environmental conditions differed in E. Thus, both varieties 'Barke' and 'Aura DS' responded more sensitively to moisture abundance than 'Gustav'. The results of the present study are in conformity with the findings of Anyia and Herzog (2004) who reported that well-watered plants had clearly the highest $\mathrm{E}$ and $\mathrm{A}$, compared with water stressed, but contrasts between varieties were different. Waraich et al. (2011 b) also indicated that sufficient water supply significantly $(P \leq 0.01)$ affected the $\mathrm{E}$ and gs of wheat and the limiting irrigation resulted in a decrease of $E$ ranging from $12 \%$ to $33 \%$.

The study of other researchers confirmed the existence of varietal differences in E. Gorny and Garczynski (2002) reported that cultivars of winter wheat contributed to the significant $(0.339, P \leq 0.01)$ variation of E. However, the result of the study with naked and hulled oat (Avena sativa L.) revealed the contrary fact; there were no differences in E between the two varieties (Zhao et al., 2011). Averaged across varieties, with increasing $\mathrm{SD}, \mathrm{E}$ values tended to decrease in 2008 (Table 3). The highest $\mathrm{E}$ was in $\mathrm{SD} \mathrm{I}$ at $\mathrm{BBCH} 31, \mathrm{BBCH} 59$ and $\mathrm{BBCH}$ 71 and in SD II at BBCH 45. Contrasts between different SDs were significant in two of the tested cases, for SD II vs. SD I at BBCH 31 and BBCH $59(P \leq 0.05)$ and SD III vs. SD II at BBCH $59(P \leq 0.05)$. Averaged across varieties in 2009, the highest $\mathrm{E}$ was established for the lowest stand density SD I in most cases (Table 4). The differences between SDs were significant in $25 \%$ of the tested cases. E differed for SD II $v s$. SD I by $0.69 \mathrm{mmol}$ $\mathrm{H}_{2} \mathrm{O} \mathrm{m}^{-2} \mathrm{~s}^{-1}(P \leq 0.01)$ and by $0.45 \mathrm{mmol} \mathrm{H}_{2} \mathrm{O} \mathrm{m}^{-2} \mathrm{~s}^{-1}$ $(P \leq 0.05)$, respectively at $\mathrm{BBCH} 59$ and $\mathrm{BBCH}^{2} 71$, and for SR III $v s$. SR I differed by $0.53 \mathrm{mmol} \mathrm{H}_{2} \mathrm{O} \mathrm{m} \mathrm{m}^{-2} \mathrm{~s}^{-1}$ $(P \leq 0.01)$ at $\mathrm{BBCH} 59$. In general, E of flag leaf decreased with increasing SD. As a result, an increase in the SD could be considered a stress condition. The plants in a denser stand have inter-competition pressure not only for nutrition, but also for soil moisture and light and a lower water supply and light intensity inside the stand leads to a lower carbon gain of the individual plants (Del Pozo, Dennett, 1999). In our study, the decrease of $E$ can be explained by the assumption that reduction of humidity, light and nutrients, especially potassium and magnesium, in the denser crop caused transpiration decreases as indicated by other researchers (Waraich et al., 2011 a).

Variation of instantaneous water use efficiency (WUEi) and stomatal conductance (gs) of spring barley. The mean across SD of instantaneous WUE $i$ was the highest for variety 'Aura DS' in most cases, the values were higher by $7.9 \%(P \leq 0.05), 9.7 \%$ and $18.5 \%$ at $\mathrm{BBCH} 31, \mathrm{BBCH} 59$ and $\mathrm{BBCH} 71$, respectively, compared with mean of trial in 2008 (Table 5). At BBCH 45 , the highest $\left(6.95 \mu \mathrm{mol} \mathrm{mmol}{ }^{-1}\right)$ WUE $i$ was established for variety 'Barke' and the value was $35.2 \%$ higher than mean of trial at the same GS. Under dry conditions during growth period (Table 1), WUE $i$ decreased in the following sequence: 'Aura DS'> 'Barke'> 'Gustav'.

Table 5. Effects of variety and stand density (SD) on instantaneous water use efficiency (WUEi) $\left(\mu \mathrm{mol} \mathrm{mmol}^{-1}\right)$ and stomatal conductance $(\mathrm{gs})\left(\mathrm{mol} \mathrm{m}^{-2} \mathrm{~s}^{-1}\right)$ in 2008

\begin{tabular}{|c|c|c|c|c|c|c|c|c|c|}
\hline \multirow{2}{*}{ Variety } & \multirow{2}{*}{ SD } & \multicolumn{2}{|c|}{ BBCH 31} & \multicolumn{2}{|c|}{ BBCH 45} & \multicolumn{2}{|c|}{ BBCH 59} & \multicolumn{2}{|c|}{ BBCH 71} \\
\hline & & WUE $i$ & gs & WUE $i$ & gs & WUE $i$ & gs & WUE $i$ & gs \\
\hline \multirow{3}{*}{ 'Aura DS' } & SD I & 4.62 & 0.51 & 3.60 & 0.17 & 2.73 & 0.27 & 2.06 & 1.02 \\
\hline & SD II & 5.53 & 0.23 & 3.93 & 0.12 & 2.99 & 0.27 & 1.46 & 0.22 \\
\hline & SD III & 4.55 & 0.60 & 3.40 & 0.13 & 3.08 & 0.27 & 2.07 & 0.12 \\
\hline \multirow{3}{*}{ 'Barke' } & SD I & 4.62 & 0.74 & 9.91 & 0.16 & 2.08 & 0.38 & 1.89 & 0.19 \\
\hline & SD II & 4.61 & 0.40 & 5.49 & 0.18 & 3.92 & 0.17 & 1.95 & 0.10 \\
\hline & SD III & 4.41 & 0.65 & 5.45 & 0.16 & 1.81 & 0.17 & 1.27 & 0.15 \\
\hline \multirow{3}{*}{ 'Gustav' } & SD I & 4.53 & 0.65 & 3.85 & 0.11 & 2.48 & 0.37 & 1.57 & 0.11 \\
\hline & SD II & 3.02 & 0.63 & 2.87 & 0.18 & 2.16 & 0.29 & 0.58 & 0.07 \\
\hline & SD III & 4.99 & 0.40 & 7.74 & 0.18 & 2.82 & 0.24 & 1.24 & 0.06 \\
\hline \multicolumn{10}{|c|}{ Mean across SDs ${ }^{\mathrm{a}}$} \\
\hline 'Aura DS' & & $4.90 \mathrm{a}$ & $0.14 b$ & $3.64 \mathrm{~b}$ & $0.14 \mathrm{~b}$ & $2.94 \mathrm{~b}$ & $0.27 \mathrm{~b}$ & $1.86 \mathrm{~b}$ & $0.46 \mathrm{~b}$ \\
\hline 'Barke’' & & $4.55 \mathrm{~b}$ & $0.16 \mathrm{~b}$ & $6.95 \mathrm{~b}$ & $0.16 \mathrm{~b}$ & $2.61 \mathrm{~b}$ & $0.24 \mathrm{~b}$ & $1.70 \mathrm{~b}$ & $0.14 \mathrm{~b}$ \\
\hline 'Gustav' & & $4.18 \mathrm{c}$ & $0.16 \mathrm{~b}$ & $4.82 \mathrm{~b}$ & $0.16 \mathrm{~b}$ & $2.49 \mathrm{~b}$ & $0.30 \mathrm{~b}$ & $1.13 \mathrm{~b}$ & $0.08 \mathrm{~b}$ \\
\hline \multicolumn{10}{|c|}{ Mean across varieties ${ }^{\mathrm{a}}$} \\
\hline & SD I & $4.59 \mathrm{~b}$ & $0.14 \mathrm{~b}$ & $5.79 \mathrm{~b}$ & $0.14 \mathrm{~b}$ & $2.43 \mathrm{~b}$ & $0.34 \mathrm{a}$ & $1.84 \mathrm{~b}$ & $0.44 \mathrm{~b}$ \\
\hline & SD II & $4.38 \mathrm{~b}$ & $0.16 b$ & $4.10 \mathrm{~b}$ & $0.16 \mathrm{~b}$ & $3.03 \mathrm{~b}$ & $0.24 \mathrm{~b}$ & $1.33 \mathrm{~b}$ & $0.13 \mathrm{~b}$ \\
\hline & SD III & $4.65 \mathrm{~b}$ & $0.16 \mathrm{~b}$ & $5.53 \mathrm{~b}$ & $0.15 \mathrm{~b}$ & $2.57 \mathrm{~b}$ & $0.23 \mathrm{~b}$ & $1.53 \mathrm{~b}$ & $0.11 \mathrm{~b}$ \\
\hline Mean & rial & 4.54 & 0.15 & 5.14 & 0.15 & 2.68 & 0.27 & 1.57 & 0.23 \\
\hline \multicolumn{10}{|c|}{ Significance } \\
\hline \multirow{3}{*}{\multicolumn{2}{|c|}{$\begin{array}{c}\text { Variety }(\text { factor A) } \\
\text { SD (factor B) } \\
A \times B\end{array}$}} & $*$ & ns & $\mathrm{ns}$ & ns & ns & ns & ns & ns \\
\hline & & ns & ns & ns & ns & ns & ns & ns & ns \\
\hline & & $* *$ & ns & ns & ns & ns & ns & ns & ns \\
\hline
\end{tabular}

Explanations under Table 3 
Under wet weather conditions in 2009 (Table 1), averaged across SD, the highest WUE $i$ was recorded for 'Gustav', and the values decreased in the following sequence: 'Gustav' > 'Barke' > 'Aura DS' (Table 6).
WUE $i$ for 'Gustav' was higher by $15.2 \%(P \leq 0.01)$, $16.4 \%(P \leq 0.01), 24.2 \%$ and $68.2 \%(P \leq 0.01)$ at $\mathrm{BBCH}$ $31, \mathrm{BBCH} 45, \mathrm{BBCH} 59$ and $\mathrm{BBCH} 71$, respectively, compared to mean of trial.

Table 6. Effects of variety and stand density (SD) on instantaneous water use efficiency (WUEi) $\left(\mu \mathrm{mol} \mathrm{mmol}^{-1}\right)$ and $^{-1}$ stomatal conductance $(\mathrm{gs})\left(\mathrm{mol} \mathrm{m} \mathrm{m}^{-2} \mathrm{~s}^{-1}\right)$ in 2009

\begin{tabular}{|c|c|c|c|c|c|c|c|c|c|}
\hline \multirow{2}{*}{ Variety } & \multirow{2}{*}{$\mathrm{SD}$} & \multicolumn{2}{|c|}{ BBCH 31} & \multicolumn{2}{|c|}{ BBCH 45} & \multicolumn{2}{|c|}{ BBCH 59} & \multicolumn{2}{|c|}{ BBCH 71} \\
\hline & & WUE $i$ & gs & WUE $i$ & gs & WUE $i$ & gs & WUE $i$ & gs \\
\hline \multirow{3}{*}{ 'Aura DS' } & SD I & 1.72 & 0.57 & 1.69 & 0.57 & 0.86 & 0.63 & 0.27 & 0.50 \\
\hline & SD II & 2.60 & 0.55 & 2.45 & 0.66 & 1.26 & 0.54 & 0.63 & 0.39 \\
\hline & SD III & 2.19 & 0.63 & 1.37 & 0.53 & 2.11 & 0.79 & 1.34 & 0.41 \\
\hline \multirow{3}{*}{ 'Barke' } & SD I & 2.88 & 0.61 & 2.00 & 0.61 & 1.08 & 0.98 & 1.34 & 0.46 \\
\hline & SD II & 3.47 & 0.57 & 2.57 & 0.80 & 1.94 & 2.62 & 1.36 & 0.57 \\
\hline & SD III & 2.76 & 0.71 & 2.65 & 0.75 & 0.83 & 0.96 & 0.95 & 0.59 \\
\hline \multirow{3}{*}{ 'Gustav' } & SD I & 2.45 & 0.55 & 2.53 & 0.53 & 1.91 & 4.58 & 2.13 & 0.78 \\
\hline & SD II & 3.80 & 0.74 & 2.53 & 0.63 & 1.86 & 0.86 & 3.16 & 2.83 \\
\hline & SD III & 3.49 & 0.59 & 3.05 & 0.79 & 1.94 & 1.04 & 2.18 & 0.75 \\
\hline \multicolumn{10}{|c|}{ Mean across SDs ${ }^{\mathrm{a}}$} \\
\hline 'Aura DS' & & $2.17 \mathrm{c}$ & $0.58 \mathrm{~b}$ & $1.84 \mathrm{c}$ & $0.59 \mathrm{~b}$ & $1.41 \mathrm{~b}$ & $0.65 \mathrm{c}$ & $0.75 \mathrm{c}$ & $0.43 \mathrm{c}$ \\
\hline 'Barke' & & $3.04 \mathrm{~b}$ & $0.63 \mathrm{~b}$ & $2.41 \mathrm{~b}$ & $0.72 \mathrm{~b}$ & $1.29 \mathrm{~b}$ & $1.52 \mathrm{~b}$ & $1.22 \mathrm{~b}$ & $0.53 \mathrm{~b}$ \\
\hline 'Gustav' & & $3.25 \mathrm{a}$ & $0.62 \mathrm{~b}$ & $2.70 \mathrm{a}$ & $0.65 \mathrm{~b}$ & $1.90 \mathrm{c}$ & $2.16 \mathrm{a}$ & $2.49 \mathrm{a}$ & $1.45 \mathrm{a}$ \\
\hline \multicolumn{10}{|c|}{ Mean across varieties ${ }^{\mathrm{a}}$} \\
\hline & SD I & $2.35 \mathrm{c}$ & $0.57 \mathrm{~b}$ & $2.07 \mathrm{c}$ & $0.57 \mathrm{~b}$ & $1.28 \mathrm{~b}$ & $2.06 \mathrm{~b}$ & $1.25 \mathrm{~b}$ & $0.52 \mathrm{~b}$ \\
\hline & SD II & $3.29 \mathrm{a}$ & $0.62 \mathrm{~b}$ & $2.52 \mathrm{a}$ & $0.69 \mathrm{~b}$ & $1.69 \mathrm{~b}$ & $1.34 \mathrm{~b}$ & $1.72 \mathrm{~b}$ & $1.24 \mathrm{a}$ \\
\hline & SD III & $2.81 \mathrm{~b}$ & $0.64 \mathrm{~b}$ & $2.36 \mathrm{~b}$ & $0.69 \mathrm{~b}$ & $1.62 \mathrm{~b}$ & $0.93 \mathrm{a}$ & $1.49 \mathrm{~b}$ & $0.65 \mathrm{~b}$ \\
\hline Mear & trial & 2.82 & 0.61 & 2.32 & 0.65 & 1.53 & 1.44 & 1.48 & 0.80 \\
\hline \multicolumn{10}{|c|}{ Significance } \\
\hline \multirow{3}{*}{\multicolumn{2}{|c|}{$\begin{array}{c}\text { Variety (factor A) } \\
\mathrm{SD}(\text { factor } \mathrm{B}) \\
\mathrm{A} \times \mathrm{B}\end{array}$}} & $* *$ & ns & $* *$ & $\mathrm{~ns}$ & ns & $*$ & $* *$ & $* *$ \\
\hline & & $* *$ & ns & $*$ & ns & ns & ns & ns & $*$ \\
\hline & & $*$ & ns & $* *$ & ns & ns & $*$ & $*$ & $* *$ \\
\hline
\end{tabular}

Explanations under Table 3

WUE $i$ is determined from the simultaneous measurement of $\mathrm{CO}_{2}$ assimilation $\left(\mu \mathrm{mol} \mathrm{CO}_{2} \mathrm{~m}^{-2} \mathrm{~s}^{-1}\right)$ and transpiration $\left(\mathrm{mmol} \mathrm{H}_{2} \mathrm{O} \mathrm{m}^{-2} \mathrm{~s}^{-1}\right)$ of a leaf or whole plant at a given point in time (Tian et al., 2011). Knowledge of the physiological traits that limit yields has improved in recent years (Jiang et al., 2006; Tsialtas, Maslaris, 2008; Ko, Piccinni, 2009). This has created new opportunities for plant breeders who can now focus on new genotypes with higher WUE $i$ (Tambussi et al., 2005; Hui et al., 2008). Differences of WUE $i$ between varieties were also indicated by other researchers. WUE $i$ of winter wheat cultivars ranged from 7.74 to $9.61 \mathrm{mmol} \mathrm{mol}^{-1}$ and cultivars contributed to the significant $(P \leq 0.01)$ variation of the leaf photosynthetic characteristics (Gorny, Garczynski, 2002). However, in contrast to our result, Jiang et al. (2006) and Zhao et al. (2011) reported that there were no significant differences in WUE $i$ between 14 barley and 2 oat genotypes, respectively. With increasing spring barley SDs, mean of WUE $i$ across varieties had unequal trend at the different GS under dry weather conditions in 2008 (Table 5). The differences between SDs of WUE $i$ were insignificant (Table 5). The highest WUE $i-5.79 \mu \mathrm{mol}$ $\mathrm{mmol}^{-1}$ and $1.84 \mu \mathrm{mol} \mathrm{mmol}{ }^{-1}$ was in the lowest SD at $\mathrm{BBCH} 45$ and $\mathrm{BBCH}$ 71, respectively, and in SD III and SD II at the other GS. Averaged across varieties in 2009, the highest WUE $i$ was established in SD II at all measurements, and contrasts SD II $v s$. SD I were higher by $40.0 \%$ at $\mathrm{BBCH} 31(P \leq 0.01), 21.7 \%$ at $\mathrm{BBCH} 45$ $(P \leq 0.05), 32.0 \%$ at $\mathrm{BBCH} 59$ and $37.6 \%$ at $\mathrm{BBCH}$ $71(P \leq 0.05)$. The values decreased in the following sequence: SD II $>$ SD III $>$ SD I (Table 6).

Mean WUEi of trial declined from BBCH 59 in both years. Genotypic response of gs was similar to $\mathrm{E}$ in most of the tested cases in 2008 (Table 5). Averaged across
$\mathrm{SD}$, gs decreased in the following sequence: 'Gustav' $>$ 'Barke' $>$ 'Aura DS' in most of the measurements in 2009 (Table 6). Significant positive contrast $(P \leq 0.01)$ was only for 'Gustav' vs. trial mean at BBCH 71. The contrast 'Aura DS' $v s$. trial mean was significant negative $(P \leq 0.01)$ at BBCH 59 and BBCH 71 . The study of other researchers confirmed the existence of varietal differences in gs of rice, the differences in gs ranged between about 0.8 and $0.9 \mathrm{~mol} \mathrm{~m}^{-2} \mathrm{~s}^{-1}$ (Takai et al., 2010). The gs of barley breeding lines ranged from 0.022 to $0.057 \mathrm{~mol} \mathrm{~m}^{-2}$ $\mathrm{s}^{-1}(P \leq 0.001)$ (Jiang et al., 2006). Gonzalez et al. (2010) also confirms significant varietal influence on gs for barley $(P<0.001)$. Varietal influence on gs can be explained by different response of varieties to solar radiation and leaf temperature differences. There are data suggesting the existence of strong relationship between canopy temperature and both gs and A. Canopy temperature was significantly correlated with gs $(r=-0.93, P<0.01)$ and with A $(r=-0.91, P<0.01)$ (Takai et al., 2010). The differences in leaf temperatures between varieties ranged between $0.9^{\circ} \mathrm{C}$ and $1.7^{\circ} \mathrm{C}$. Ko and Piccinni (2009) have also reported that leaf temperature strongly and significantly correlates with A and gs. However, conflicting data have been obtained by Zhao et al. (2011) who states that varietal influence on gs was not significant for two varieties of oats. Averaged across varieties, gs was similar in different SDs at $\mathrm{BBCH} 31$ and $\mathrm{BBCH} 45$ in 2008 (Table 5). The highest gs $\left(0.34\right.$ and $0.44 \mathrm{~mol} \mathrm{~m}^{-2}$ $\mathrm{s}^{-1}$ ) were in the lowest SD I, respectively at BBCH 59 and $\mathrm{BBCH} 71$. The contrasts SD II vs. SD I and SD III vs. SD I were significant $(P \leq 0.05)$ only at $\mathrm{BBCH} 59$ in 2008 . The contrasts SD III $v s$. SD I were significant $(P \leq 0.05)$ at BBCH 59, SD II $v s$. SD I and SD II $v s$. SD III were significant $(P \leq 0.05)$ at BBCH 71 (Table 6). 
Relationship between phyciological parameters and meteorological factors. The leaf gas exchange parameters could be viewed as sensitive response factors of the plant to abiotic stress (Zhao et al., 2011). The simple correlation analysis confirmed the existence of the correlation between the physiological parameters of spring barley and meteorological factors from sowing throughout the growing season. However, differences among the SDs and varieties were noticed in the strength of the relationship among the variables as shown by the values of the correlation coefficients in Table 7 .

Table 7. Simple correlation coefficients between physiological parameters and meteorological factors (2008-2009)

\begin{tabular}{|c|c|c|c|c|c|c|}
\hline & $\begin{array}{c}\text { Mean air } \\
\text { temperature } \\
{ }^{\circ} \mathrm{C}\end{array}$ & $\begin{array}{l}\text { Precipitation } \\
\mathrm{mm}\end{array}$ & $\mathrm{GDD} \geq 5^{\circ} \mathrm{C}^{1}$ & $\mathrm{GDD} \geq 10^{\circ} \mathrm{C}^{2}$ & $\begin{array}{c}\text { Sunshine } \\
\text { duration } \\
\mathrm{h}\end{array}$ & $\begin{array}{c}\text { Relative air } \\
\text { humidity } \\
\%\end{array}$ \\
\hline \multicolumn{7}{|c|}{$\mathrm{A}$} \\
\hline \multicolumn{7}{|c|}{ Mean across varieties } \\
\hline SD I & $-0.280^{*}$ & $-0.459 * *$ & $-0.585 * *$ & $-0.581 * *$ & $-0.524 * *$ & $-0.233^{*}$ \\
\hline SD II & $-0.316^{* *}$ & $-0.374 * *$ & $-0.575 * *$ & $-0.587 * *$ & $-0.495 * *$ & $-0.325 * *$ \\
\hline SD III & $-0.291 * *$ & $-0.380 * *$ & $-0.620 * *$ & $-0.618 * *$ & $-0.560 * *$ & -0.131 \\
\hline \multicolumn{7}{|c|}{ Mean across SDs } \\
\hline 'Aura DS' & $-0.273 *$ & $-0.528 * *$ & $-0.537 * *$ & $-0.531 * *$ & $-0.466^{*}$ & $-0.307 * *$ \\
\hline 'Barke' & $-0.287^{*}$ & $-0.458 * *$ & $-0.661 * *$ & $-0.654 * *$ & $-0.594 * *$ & -0.200 \\
\hline 'Gustav' & $-0.337 * *$ & $-0.263^{*}$ & $-0.599 * *$ & $-0.616^{* *}$ & $-0.530 * *$ & -0.116 \\
\hline \multicolumn{7}{|c|}{$\mathrm{E}$} \\
\hline \multicolumn{7}{|c|}{ Mean across varieties } \\
\hline SD I & 0.012 & 0.208 & -0.098 & -0.132 & -0.059 & $0.57 * *$ \\
\hline SD II & -0.091 & 0.080 & -0.216 & $-0.245^{*}$ & -0.157 & $0.469 * *$ \\
\hline SD III & -0.057 & 0.112 & -0.216 & $-0.254^{*}$ & -0.176 & $0.514 * *$ \\
\hline \multicolumn{7}{|c|}{ Mean across SDs } \\
\hline 'Aura DS' & -0.076 & $0.247 *$ & -0.046 & -0.057 & 0.020 & $0.504^{*}$ \\
\hline 'Barke' & 0.041 & 0.214 & -0.182 & -0.220 & -0.162 & $0.580 * *$ \\
\hline 'Gustav' & -0.092 & -0.015 & $-0.273^{*}$ & $-0.322 * *$ & -0.220 & $0.486 * *$ \\
\hline \multicolumn{7}{|c|}{ gs } \\
\hline \multicolumn{7}{|c|}{ Mean across varieties } \\
\hline SD I & 0.194 & 0.221 & 0.037 & 0.011 & -0.018 & $0.271 *$ \\
\hline SD II & 0.100 & $0.497 * *$ & 0.036 & 0.031 & -0.014 & $0.406 * *$ \\
\hline SD III & -0.135 & $0.377 * *$ & $-0.271 *$ & $-0.301 * *$ & $-0.334 * *$ & $0.409 * *$ \\
\hline \multicolumn{7}{|c|}{ Mean across SDs } \\
\hline 'Aura DS' & -0.036 & 0.144 & 0.012 & -0.009 & -0.014 & 0.193 \\
\hline 'Barke' & 0.088 & $0.342 * *$ & -0.142 & -0.181 & -0.217 & $0.424 * *$ \\
\hline 'Gustav' & 0.179 & $0.425 * *$ & 0.034 & 0.024 & -0.023 & $0.363 * *$ \\
\hline \multicolumn{7}{|c|}{ WUE $i$} \\
\hline \multicolumn{7}{|c|}{ Mean across varieties } \\
\hline SD I & -0.098 & $-0.316^{* *}$ & $-0.320 * *$ & $-0.298 * *$ & $-0.305 * *$ & $-0.352 * *$ \\
\hline SD II & $-0.317 * *$ & $-0.404 * *$ & $-0.573 * *$ & $-0.553 * *$ & $-0.547 * *$ & $-0.399 * *$ \\
\hline SD III & -0.158 & $-0.359 * *$ & $-0.436^{* *}$ & $-0.412 * *$ & $-0.418^{* *}$ & $-0.386^{* *}$ \\
\hline \multicolumn{7}{|c|}{ Mean across SDs } \\
\hline 'Aura DS' & $-0.308 * *$ & $-0.617 * *$ & $-0.584 * *$ & $-0.561 * *$ & $-0.578 * *$ & $-0.697 * *$ \\
\hline 'Barke' & -0.102 & $-0.341 * *$ & $-0.358 * *$ & $-0.337 * *$ & $-0.332 * *$ & $-0.332 * *$ \\
\hline 'Gustav' & -0.187 & -0.221 & $-0.427 * *$ & $-0.404 * *$ & $-0.410 * *$ & $-0.258^{*}$ \\
\hline
\end{tabular}

Notes. ${ }^{1}$ - baseline temperature used for growing degree days (GDD) computation was $5^{\circ} \mathrm{C},{ }^{2}-$ baseline temperature used for growing degree days (GDD) computation was $10^{\circ} \mathrm{C}$. A - photosynthetic rate, SD - stand density, E - transpiration rate, gs stomatal conductance, WUE $i$ - instantaneous water use efficiency; *,** - relationship between indices is significant at $P \leq 0.05$ and $P \leq 0.01$, respectively. Mean values of air temperature $\left(12.5<{ }^{\circ} \mathrm{C}<18.7\right.$ and $\left.12.2<{ }^{\circ} \mathrm{C}<22.8\right)$, precipitation $(11.6<\mathrm{mm}<66.6$ and $35.8<\mathrm{mm}<231.6)$, GDD $\geq 5^{\circ} \mathrm{C}\left(200.1<{ }^{\circ} \mathrm{C}<746.6\right.$ and $\left.332.2<{ }^{\circ} \mathrm{C}<678.9\right)$, GDD $\geq 10^{\circ} \mathrm{C}\left(62.1<{ }^{\circ} \mathrm{C}<358.4\right.$ and 126.5 $\left.<{ }^{\circ} \mathrm{C}<346.9\right)$, sunshine duration $(267.7<\mathrm{h}<792.6$ and $437.1<\mathrm{h}<723.3)$, relative air humidity $(49<\%<61$ and $68<\%<79)$ ranged from sowing to last measurement, respectively in 2008 and 2009.

The mean of $\mathrm{A}$ across varieties and across SDs negatively correlated with all meteorological factors and the correlation was significant $(P \leq 0.05$ and $P \leq 0.01)$ in most of the tested cases. Averaged across varieties and across SDs, mean of E significantly and positively correlated $(P \leq 0.05$ and $P \leq 0.01)$ with relative air humidity. The correlation coefficients revealed that the mean of $\mathrm{E}$ across varieties and GDD $\geq 10^{\circ} \mathrm{C}$ were negatively correlated $(P \leq 0.05)$ in SD II and SD III. The mean of E across SDs negatively correlated with GDD $\geq 5^{\circ} \mathrm{C}(P \leq 0.05)$ and GDD $\geq 10^{\circ} \mathrm{C}$ $(P \leq 0.01)$ for variety 'Gustav'. The mean of gs across varieties positively correlated with relative air humidity for all SDs $(P \leq 0.05$ and $P \leq 0.01)$ and, averaged across
SDs, gs correlated $(P \leq 0.01)$ with relative air humidity for varieties 'Barke' and 'Gustav'. Averaged across varieties, gs negatively correlated with sunshine duration $(P \leq 0.01)$, $\mathrm{GDD} \geq 5^{\circ} \mathrm{C}(P \leq 0.05)$ and $\mathrm{GDD} \geq 10^{\circ} \mathrm{C}(P \leq 0.01)$ in SD III and positively correlated $(P \leq 0.01)$ with precipitation in SD II and SD III. The positive correlation between the mean of gs across SDs and precipitation was established for 'Barke' and 'Gustav'. The mean of WUE $i$ both across varieties and SDs negatively correlated $(P \leq 0.01)$ with all meteorological factors, except for mean air temperature. Conflicting data has been obtained by Evrendilek et al. (2008), who detected positive and strong correlation between air temperature and both $\mathrm{A}$ and $\mathrm{E}(P<0.001)$ of 
wheat. Takai et al. (2010) have reported that the ambient temperature determines leaf temperature. Some data indicates that canopy temperature was closely correlated with gs $(r=-0.93, P<0.01)$ and A $(r=-0.91, P<0.01)$.

As presented in the correlation matrix, mean of parameters across both varieties and SDs showed a close concordance in terms of the direction and shape of the relationship among the measured variables (Table 8). The matrix of correlation coefficients revealed that $\mathrm{A}$ positively and significantly $(P<0.01)$ correlated with E and WUE $i$ in all SDs and for all varieties, while there was a trend for a negative correlation with gs $(P>0.05)$. A negative correlation was detected both averaged across varieties and averaged across SD, between $\mathrm{E}$ and WUEi, the relationship was significant in SD I $(P<0.01)$ and SD III $(P<0.05)$ and for varieties 'Aura DS' $(P<0.01)$ and 'Barke' $(P<0.01)$. E with gs correlated positively, but the correlation was significant in $50 \%$ for all the tested cases.

Table 8. Correlation matrix of spring barley physiological parameters (2008-2009)

\begin{tabular}{|c|c|c|c|c|}
\hline & & $\begin{array}{c}\mathrm{A} \\
\mu \mathrm{mol} \mathrm{CO} \mathrm{C}_{2} \mathrm{~m}^{-2} \mathrm{~s}^{-1}\end{array}$ & $\begin{array}{c}\mathrm{E} \\
\mathrm{mmol} \mathrm{H}_{2} \mathrm{O} \mathrm{m}^{-2} \mathrm{~s}^{-1}\end{array}$ & $\begin{array}{c}\text { gs } \\
\text { mol m-2 } \mathrm{s}^{-1}\end{array}$ \\
\hline \multicolumn{5}{|c|}{ Mean across varieties } \\
\hline \multirow{3}{*}{ SD I } & $\mathrm{E}$ & $0.400 * *$ & - & \\
\hline & gs & 0.011 & 0.170 & - \\
\hline & WUE $i$ & $0.437 * *$ & $-0.334 * *$ & -0.081 \\
\hline \multirow{3}{*}{ SD II } & $\mathrm{E}$ & $0.598 * *$ & - & \\
\hline & gs & -0.054 & 0.124 & - \\
\hline & WUE $i$ & $0.624 * *$ & -0.135 & -0.106 \\
\hline \multirow{3}{*}{ SD III } & $\mathrm{E}$ & $0.475 * *$ & - & \\
\hline & gs & 0.143 & $0.433 * *$ & - \\
\hline & WUE $i$ & $0.511 * *$ & $-0.255^{*}$ & -0.139 \\
\hline \multicolumn{5}{|c|}{ Mean across SDs } \\
\hline \multirow{3}{*}{ 'Aura DS' } & $\mathrm{E}$ & $0.338 * *$ & - & \\
\hline & gs & -0.085 & $0.317 * *$ & - \\
\hline & WUE $i$ & $0.665 * *$ & $-0.395 * *$ & $-0.240 *$ \\
\hline \multirow{3}{*}{ 'Barke' } & $\mathrm{E}$ & $0.347 * *$ & - & \\
\hline & gs & -0.038 & $0.333 * *$ & - \\
\hline & WUE $i$ & $0.507 * *$ & $-0.333 * *$ & -0.174 \\
\hline \multirow{3}{*}{ 'Gustav' } & $\mathrm{E}$ & $0.693 * *$ & - & \\
\hline & gs & 0.044 & 0.095 & - \\
\hline & WUE $i$ & $0.388 * *$ & -0.150 & -0.024 \\
\hline
\end{tabular}

Note. A - photosynthetic rate, $\mathrm{E}$ - transpiration rate, gs - stomatal conductance, WUE $i$ - instantaneous water use efficiency, SD stand density; *** - relationship between indices is significant at $P \leq 0.05$ and $P \leq 0.01$, respectively.

The results of study with wheat have revealed differences in the shape and strength of correlation between A, E and gs during grain filling phases (Hui et al., 2008). During early grain filling, A was significantly positively correlated with $\mathrm{E}(P<0.01)$, while there was a trend for a negative correlation between $\mathrm{A}$ and $\mathrm{E}$ in both middle and late stage of grain filling. The results of our experiment are in line with the findings of Hui et al. (2008), who reported that there existed inconsistent correlation between A and gs, which did not show statistical significance, and strong significant correlation between $\mathrm{E}$ and gs. However, in contrast to our results, Efthimiadou et al. (2010) reported that high significant correlation $(0.792, P<0.01$ and $0.778, P<0.01)$ between A and gs was established for maize grown under field conditions The evidence of the present study revealed that mean of A across SDs was not

Table 9. Correlation coefficients of the polynomial correlation between physiological parameters and meteorological factors throughout growing season (2008-2009)

\begin{tabular}{ccccccccc}
\hline \multirow{2}{*}{ Parameter (y) } & $\begin{array}{c}\text { Mean across } \\
\text { SDs }\end{array}$ & $R$ & $R^{2}$ & $F_{\text {fact. }}$ & $\begin{array}{c}\text { Mean across } \\
\text { varieties }\end{array}$ & $R$ & $R^{2}$ & $F_{\text {fact. }}$ \\
\hline \multirow{2}{*}{ A } & 'Aura DS' & 0.722 & 0.521 & $15.68^{* *}$ & SD I & 0.722 & 0.521 & $15.68^{* *}$ \\
& 'Barke' & 0.819 & 0.671 & $29.38^{* *}$ & SD II & 0.835 & 0.698 & $33.22^{* *}$ \\
& 'Gustav' & 0.858 & 0.736 & $40.17^{* *}$ & SD III & 0.762 & 0.580 & $19.91^{* *}$ \\
\hline \multirow{2}{*}{ E } & 'Aura DS' & 0.795 & 0.633 & $20.37^{* *}$ & SD I & 0.761 & 0.580 & $16.32^{* *}$ \\
& 'Barke' & 0.782 & 0.611 & $18.61^{* *}$ & SD II & 0.808 & 0.653 & $22.29 * *$ \\
& 'Gustav' & 0.848 & 0.720 & $30.37^{* *}$ & SD III & 0.772 & 0.596 & $17.47^{* *}$ \\
\hline \multirow{2}{*}{ gs } & 'Aura DS' & 0.458 & 0.210 & $3.14^{* *}$ & SD I & 0.352 & 0.124 & $1.67 \mathrm{~ns}$ \\
& 'Barke' & 0.583 & 0.340 & $6.11^{* *}$ & SD II & 0.728 & 0.529 & $13.31^{* *}$ \\
& 'Gustav' & 0.781 & 0.610 & $18.47^{* *}$ & SD III & 0.548 & 0.300 & $5.08^{* *}$ \\
\hline \multirow{2}{*}{ WUE $i$} & 'Aura DS' & 0.795 & 0.633 & $20.38^{* *}$ & SD I & 0.453 & 0.205 & $3.06^{*}$ \\
& 'Barke' & 0.498 & 0.248 & $3.90^{* *}$ & SD II & 0.628 & 0.394 & $7.69^{* *}$ \\
& 'Gustav' & 0.490 & 0.240 & $3.74^{* *}$ & SD III & 0.546 & 0.298 & $5.01^{* *}$ \\
\hline
\end{tabular}

Notes. Multi regression equation $\mathrm{y}=\mathrm{a}+\mathrm{bx}_{1}+\mathrm{cx}_{2}+\mathrm{dx}_{3}+\mathrm{ex}_{4}+\mathrm{fx}_{5}$, where $\mathrm{y}-\mathrm{A}$ or $\mathrm{E}$, or gs, or WUE $i, \mathrm{x}_{1}-$ mean air temperature $\left({ }^{\circ} \mathrm{C}\right), \mathrm{x}_{2}$ - precipitation (mm), $\mathrm{x}_{3}$ - baseline temperature used for growing degree days (GDD) computation was $5^{\circ} \mathrm{C}, \mathrm{x}_{4}-$ baseline temperature used for growing degree days (GDD) computation was $10^{\circ} \mathrm{C}, \mathrm{x}_{5}$ - sunshine duration $(\mathrm{h}) . \mathrm{A}$ - photosynthetic rate, $\mathrm{E}-$ transpiration rate, gs - stomatal conductance, WUE $i$ - instantaneous water use efficiency, SD - stand density; *, ** - relationship between indices is significant at $P \leq 0.05$ and $P \leq 0.01$, respectively. 
correlated with gs for the tested varieties (Table 8). This is in conformity with the data of Anyia and Herzog (2004), who reported that correlation between $\mathrm{A}$ and gs was weak and insignificant for 10 genotypes of cowpea under wellwatered conditions. However, some other reports do not support the results of this study. In studies with rice, significant correlation between gs and A was obtained for all of seven varieties $(r=0.92, P<0.001)$, confirming previous findings that gs is an important determinant of $\mathrm{A}$ (Takai et al., 2010).

The multiple linear regression model $(y=a+$ $\mathrm{bx}_{1}+\mathrm{cx}_{2}+\mathrm{dx}_{3}+\mathrm{ex}_{4}+\mathrm{fx}_{5}$ ) showed that all physiological parameters of spring barley were intensely influenced by the weather conditions all through the growing season (Table 9). It was found that the interaction of meteorological factors influenced the mean A across SDs by 52.1, 67.1 and $73.6 \%$ for the 'Aura DS', 'Barke' and 'Gustav', respectively. The mean across SDs of E was influenced by weather conditions by $63.3,61.1$ and $72.0 \%$ for 'Aura DS', 'Barke' and 'Gustav', respectively. The influence of meteorological factors on gs was weaker for 'Aura DS' $(21.0 \%)$ and 'Barke' $(34.0 \%)$ than for 'Gustav' (61.0\%). Meteorological conditions caused $63.3 \%$ of WUE $i$ data variation for 'Aura DS' and less for other varieties $24.8 \%$ and $24.0 \%$ for 'Barke' and 'Gustav', respectively. The correlation coefficients were significant $(P<0.05$, $P<0.01)$ in all the tested cases with one exception.

\section{Conclusion}

The varietal and stand density impact on physiological parameters was significant in $50 \%$ of the tested cases under dry conditions in May-July period in 2008 and in $75 \%$ of the tested cases under dry conditions in May, but very rainy end of June and sufficiently wet July in 2009. The significant influence of growth stage on all physiological parameters was established independently of the moisture regime. The spring barley varieties differed in the tolerance of meteorological factors throughout growing season. The photosynthetic rate and transpiration values were the highest for variety 'Barke' under dry growth conditions and for 'Gustav' under abundant moisture conditions in most of the tested cases. Averaged across varieties, the highest values of photosynthetic rate, transpiration and instantaneous water use efficiency were in medium stand density (400 plants $\mathrm{m}^{-2}$ ) in most of the cases and the data of the aforementioned parameters tended to decrease with increasing stand density. All physiological parameters closely correlated with meteorological factors.

Received 01082012 Accepted 06122012

\section{References}

Abbad H., Jaafari S., Bort J., Araus J. L. 2004. Comparison of flag leaf and ear photosynthesis with biomass and grain yield of durum wheat under various water conditions and genotypes. Agronomie, 24 (1): 19-28 http://dx.doi.org/10.1051/agro:2003056

Aksyonov I. 2007. Effect of cultivation measures on index of photosynthesis and vield of sunflower. Helia, 47 (47): 79-86 http://dx.doi.org/10.2298/HEL0747079A

Anda A., Løke Z. 2005. Radiation balance components of maize hybrids grown at various plant densities. Journal of Agronomy and Crop Science, 191 (3): 202-209 http://dx.doi.org/10.1111/j.1439-037X.2005.00124.x
Anyia A.O., Herzog H. 2004. Water-use efficiency, leaf area and leaf gas exchange of cowpeas under mid-season drought. European Journal of Agronomv. 20 (4): 327-339 http://dx.doi.org/10.1016/S1161-0301(03)00038-8

Brooks T. J., Wall G. W., Pinter Jr P. J., Kimball B. A., LaMorte R. L., Leavitt S. W., Matthias A. D., Adamsen F. J., Hunsaker D. J., Webber A. N. 2000. Acclimation response of spring wheat in a free-air $\mathrm{CO}_{2}$ enrichment (FACE) atmosphere with variable soil nitrogen regimes. 3. Canopy architecture and gas exchange. Photosynthesis Research. 66 (1-2): 97-108 http://dx.doi.org/10.1023/A:1010634521467

Cai G., Zhang M., Yin Y., Wang P., Zhang T., Gu F., Dai Z., Liang T., Wu Y., Wang Z. 2008. Photosynthetic characteristics and antioxidative metabolism of flag leaves in responses to nitrogen application during grain filling of field-grown wheat. Agricultural Science in China. 7 (2): 157-167 http://dx.doi.org/10.1016/S1671-2927(08)60035-8

Del Pozo A., Dennett M. D. 1999. Analysis of the distribution of light, leaf nitrogen, and photosynthesis within the canopy of Vica faba L. at two contrasting plant densities. Australian Journal of Agricultural Research, 50 (2): 183 $189 \mathrm{http}: / / d x . d o i . o r g / 10.1071 /$ A94105

Efthimiadou A., Bilalis D., Karkanis A., Froud-Williams B. 2010. Combined organic/inorganic fertilization enhance soil quality and increased yield, photosynthesis and sustainability of sweet maize crop. Australian Journal of Crop Science, 4 (9): 722-729

Evrendilek F., Asher J. B., Aydin M. 2008. Diurnal photosynthesis, water use efficiency and light use efficiency of wheat under Mediterranean field conditions. Journal of Environmental Biology, 29 (3): 397-406

Fang Y., Bingcheng X., Turner N. C., Li F. 2010. Does root pruning increase yield and water-use efficiency of winter wheat? Crop and Pasture Science, 61 (11): 899-910 http://dx.doi.org/10.1071/CP10125

Fois S., Motzo R., Giunta F. 2009. The effect of nitrogenous fertiliser application on leaf traits in durum wheat in relation to grain yield and development. Field Crops Research. 110 (1): 69-75 http://dx.doi.org/10.1016/j.fcr.2008.07.004

Gonzalez A., Bermejo V., Gimeno B. S. 2010. Effect of different physiological traits on grain yield in barley grown under irrigated and terminal water deficit conditions. Journal of Agricultural Science. 148 (3): 319-328 http://dx.doi.org/10.1017/S0021859610000031

Gorny A., Garczynski S. 2002. Genotypic and nutrition-dependent variation in water use efficiency and photosynthetic activity of leaves in winter wheat (Triticum aestivum L.). Journal of Applied Genetics, 43 (2): 145-160

Gutierrez D., Gutierrez E., Perez P., Morcuende R., Verdejo A. L., Martinez-Carrasco R. 2009. Acclimation to future atmospheric $\mathrm{CO}_{2}$ levels increases photochemical efficiency and mitigates photochemistry inhibition by warm temperatures in wheat under field chambers. Physiologia Plantarum, 137 (1): 86-100 http://dx.doi.org/10.1111/j.1399-3054.2009.01256.x

Hui Z., ZhengBin Z., HongBo S., Ping X., Foulkes M. J. 2008. Genetic correlation and path analysis of transpiration efficiency for wheat flag leaves. Environmental and Experimental Botany. 64 (2): 128-134 http://dx.doi.org/10.1016/j.envexpbot.2007.11.001

Ibrahim M. H., Jaafar H. Z. E. 2011. Photosynthetic capacity, photochemical efficiency and chlorophyll content of three varieties of Labisia pumila Benth. exposed to open field and greenhouse growing conditions. Acta Physiologiae Plantarum. 33: 2179-2185 http://dx.doi.org/10.1007/s11738-011-0757-1

Janušauskaitė D., Auškalnienė O., Pšibišauskienė G. 2012. Photosynthetic responses of spring barley varieties to different stand densities under field conditions. Acta Agriculturae Scandinavica, Section B: Soil and Plant Science, 62 (5): 441-448

Jiang Q., Roche D., Monaco T. A., Durham S. 2006. Gas exchange, chlorophyll fluorescence parameters and carbon 
isotope discrimination of 14 barley genetic lines in response to salinity. Field Crops Research, 96: 269-278

http://dx.doi.org/10.1016/j.fcr.2005.07.010

Kalaji H. M., Govindjee, Bosa K., Kościelniak J., ŻukGołaszewska K. 2011. Effects of salt stress on photosystem II efficiency and $\mathrm{CO}_{2}$ assimilation of two Syrian barley landraces. Environmental and Experimental Botany, 73: 64-72 http://dx.doi.org/10.1016/j.envexpbot.2010.10.009

Ko J., Piccinni G. 2009. Characterizing leaf gas exchange responses of cotton to full and limited irrigation conditions. Field Crops Research, 112 (1): 77-89 http://dx.doi.org/10.1016/j.fcr.2009.02.007

Long S. P., Zhu X., Naidu S. L., Ort D. R. 2006. Can improvement in photosynthesis increase crop yields? Plant, Cell and Environment, 29 (3): 315-330 http://dx.doi.org/10.1111/j.1365-3040.2005.01493.x

Mamnouie E., Fotouhi Ghazvini R., Esfahany M., Nakhoda B. 2006. The effects of water deficit on crop yield and the physiological characteristics of barley (Hordeum vulgare L.) varieties. Journal of Agriculture, Science and Technology, 8: 211-219

Niu S., Li Z., Xia J., Han Y., Wu M., Wan S. 2008. Climatic warming changes plant photosynthesis and its temperature dependence in a temperate steppe of northern China. Environmental and Experimental Botany, 63 (1-3): 91$101 \mathrm{http}: / / \mathrm{dx}$.doi.org/10.1016/j.envexpbot.2007.10.016

Takai T., Yano M., Yamamoto T. 2010. Canopy temperature on clear and cloudy days can be used to estimate varietal differences in stomatal conductance in rice. Field Crops Research, 115 (2): 165-170 http://dx.doi.org/10.1016/j.fcr.2009.10.019
Tambussi E. A., Nogues S., Ferrio P., Voltas J., Araus J. L. 2005. Does higher yield potential improve barley performance in Mediterranean conditions? A case study. Field Crops Research, 91: 149-160 http://dx.doi.org/10.1016/j.fcr.2004.06.002

Tian Z., Jing Q., Dai T., Jiang D., Cao W. 2011. Effect of genetic improvements on grain yield and agronomic traits of winter wheat in the Yangtze River Basin of China. Field Crops Research, 124 (3): 417-425 http://dx.doi.org/10.1016/j.fcr.2011.07.012

Tsialtas J. T., Maslaris N. 2008. Seasonal trends and relationships of light, temperatures and leaf physiologicals traits of sugar beets (Beta vulgaris L.) grown under semi-arid, Mediterranean conditions. International Journal of Plant Production, 2 (3): 223-242

Waraich E. A., Ahmad R., Ashraf M. Y., Saifullah, Ahmad M. 2011 (a). Improving agricultural water use efficiency by nutrient management in crop plants. Acta Agriculturae Scandinavica, Section B: Soil and Plant Science, 61 (4): 291-304

Waraich E. A., Ahmad R., Saifullah, Ahmad A. 2011 (b). Water stress and nitrogen management effects on gas exchange, water relation, and water use efficiency in wheat. Journal of Plant Nutrition, 34 (12): 1867-1882

Zhao B. P., Ma B. L., Hu Y. G., Liu J. H. 2011. Leaf photosynthesis, biomass production and water and nitrogen use efficiencies of two contrasting naked $v s$. hulled oat genotypes subjected to water and nitrogen stress. Journal of Plant Nutrition, 34 (14): 2139-2157 http://dx.doi.org/10.1080/01904167.2011.618574

ISSN 1392-3196 / e-ISSN 2335-8947

Zemdirbyste-Agriculture, vol. 100, No. 2 (2013), p. 127-136

DOI $10.13080 / \mathrm{z}-\mathrm{a} .2013 .100 .016$

\title{
Agronominių priemonių ir meteorologinių sąlygų ịtaka paprastojo miežio (Hordeum vulgare L.) fiziologiniams rodikliams
}

\author{
D. Janušauskaitė, O. Auškalnienè, D. Feizienė, V. Feiza \\ Lietuvos agrarinių ir miškų mokslų centro Žemdirbystès institutas
}

\begin{abstract}
Santrauka
Yra nedaug duomenu apie pasèlio tankumo ittaką vasarinio miežio (Hordeum vulgare L.) fiziologiniams rodikliams, lemiantiems augalu produktyvumą. Tyrimų tikslas - nustatyti vasarinio miežio veisliu fiziologiniu rodiklių skirtumus esant skirtingam pasèlio tankumui ir ịvertinti fiziologinių rodiklių bei meteorologinių sąlygų sąveiką Vidurio Lietuvoje. Auginti trijų veislių miežiai - 'Aura DS', 'Barke' ir 'Gustav', suformuojant skirtingo tankumo pasèli - 200, 400 ir 600 augalų $\mathrm{m}^{2}$. Fiziologinių rodiklių vertinimas atliktas keturis kartus per vegetacijos laikotarpi. Veislès ir pasèlio tankumo ịtaka fotosintezės grynajam rodikliui (A), transpiracijai (E), žiotelių laidumui (gs) bei vandens eikvojimo efektyvumui (WUEi) buvo didesné esant drégnoms vegetacijos laikotarpio sąlygoms nei esant sausiems orams. Vasarinio miežio veislès tarpusavyje skyrėsi meteorologinių sąlygų tolerancija per vegetacijos laikotarpị. Veislès 'Barke' miežių fotosintezès grynasis rodiklis buvo didesnis esant sausiems, o veislès 'Gustav' - drègniems vegetacijos laikotarpio orams. Fiziologinių rodiklių atžvilgiu optimalus buvo 400 augalų $\mathrm{m}^{2}$ pasèlio tankumas. Pasèlio tankumui didèjant arba mažèjant, lyginant su optimaliu, fotosintetinių rodiklių vertès tendencingai mažèjo daugeliu tirtų atvejų. Meteorologinių veiksnių sąveika turèjo įtakos 52,1, 67,1 bei 73,6\% fotosintezès grynojo rodiklio ir 63,3, 61,1 bei 72,0\% transpiracijos atitinkamai veislių 'Aura DS', 'Barke' ir 'Gustav' miežiams.
\end{abstract}

